\title{
丸太運輸(株)東海物流センターにおけるコイル置場管理
}

井上哲男 $*$ ，松永和晴*

\section{Coil Inventory Management in the Tokai Logistics Center, Maruta Transportat Co., Ltd.}

\author{
Tetsuo Inoue and Yoshiharu Matsunaga
}

\section{Synopsis}

The tokai logistics center (Maruta Transport Co., Ltd.) is 20866 sqm site with 10000 sqm accommodation. One of the mainly warehoused items is coil. Before introduction of a new inventory system, operators needed to crawl under a pile of coils to check the bar-coded tags. The manner practiced there was unsafe and quite inefficient for the workers; in spite of the fact that automated transportation crane position management systems had been employed effectively at many other warehouses.

Now high-performance computers with a smooth three-dimensional displaying capability are readily available in the market and that is the main reason we created "The Maruta Tokai Warehouse Inventory Management System" to eradicate the above mentioned time-consuming and risky operations there.

In 2004, we completed the new system that showed warehouse situation to the crane operators in real-time.

Outline of the system, the method of warehouse management and principle of the crane navigation is described in this paper.

\section{1. 緒言}

丸太運輸(株)東海物流センター (以下, 東海物流センター という) は, 愛知県東海市に位置し, 敷地面積 $20866 \mathrm{~m}^{2}$, 倉庫面積 $10000 \mathrm{~m}^{2}$ の鋼材を保管する倉庫である. 取り扱 い製品は主として，線材製品（以下，コイルという），棒 鋼製品 (以下，バーという)，平板製品がありその $80 \%$ が 大同特殊鋼(株)製品である。

東海物流センターでは, 置場管理がシステム化されてお らず，全て人間系により管理されていた。コイル置場運用 としては, 向け先別にあらかじめ決められた置場にコイル を置いているが, 在庫量の増加に伴い決められた置場外に 置くこともあった. そのため, 出荷準備に伴う現品確認に 関しては, 置場のコイルに潜って付けられた荷札バーコー ドを照合チェックする必要があった。また，コイル径は約 $1500 \mathrm{~mm}$ であり, 4 段に積んで保管している.したがって,
潜り作業を行う位置は地上約 $5 \mathrm{~m}$ に達する場合がある。こ のことからコイル内に潜るという不安全作業が危険視さ れていた. また, このコイルの置場運用の方法は作業効率 が非常に悪いため, 作業者にとって大きな負担となってい た。

一方, 置場を管理するシステムとしては, 置場位置を固 定した自動倉庫でのシステムと, 置場位置が固定されてい ない倉庫において, クレーンの位置を検知することによる 座標把握と, クレーンにかかる荷重を取得することによる コイルの吊り降し認識によってコイル搬送を認識するシ ステムがある.後者においては人間系で管理してきた倉庫 にそのまま流用できる利点がある。

また昨今のパソコンは, 処理速度が向上してきたこと で，なめらかな3D 画像を表示できるものが安価に利用で きるようになった。

このような背景から, 東海物流センターにてコイル置場 
におけるコイル内潜り作業による確認作業の撲滅を狙い, コイルの置場状況をリアルタイムにクレーン運転者へナ ビゲーションする「丸太東海倉庫置場管理システム」(以 下，本システムという）を 2004 年に完成した.

本論では本システムの概略, 置場管理にあたっての考元 方, クレーンナビゲーションについて述べる.

\section{2. 東海物流センターにおける 従来のコイル業務}

\section{1 コイルの入出荷業務の概要}

(1) 置場管理の考え方

コイル置場は，向け先別に大まかに決められており，同一 向け先のコイルが固まった置場となるように運用している. (2) 入荷作業

コイルは, 大同特殊鋼(侏)の工場から東海物流センターへ トラックにて搬入されてくる. 入荷作業者は別送の入荷指 示書とコイルに随伴している荷札バーコードとの照合 チェックを行う。その際コイルに対し, 向け先別に色テー プを貼り,クレーン作業者からどの向け先のコイルかを判 別できるようにしておく.クレーン作業者はその色テープ を見て，向け先別の置場に搬入している.

(3) 出荷準備作業（配置替之作業）

事務所に抒いて出荷予定指示を作成するが, 早ければ一 週間前, 遅くて $2 \cdot 3$ 日前に決定する客先の納入指示を元 に，出荷予定指示を行う．出荷予定指示がされると，まず は出荷指示コイルの現状位置を, 置場に並べられたコイル に随伴している荷札バーコードを 1 つずつコイルに潜っ て照合チェックし, 対象コイルを探す。照合チェックが終 了すると手書きにて置場表を作成する.クレーン作業者が その置場表を見ながら実際のコイル搬送を行い, コイルの 配置を変更し出荷対象コイルをまとめて出荷に備える.

(4) 出荷作業

事務所にて出荷日が正式に確定すると出荷指示書を作 成する.出荷指示書と出荷準備作業にて作成した置場表を 参照し, 置場のコイルに潜り出荷対象コイルの荷札バー コードの現品確認を行う. 現品確認ができるとクレーンに てトラックへの搬送を行う.トラックでは, 荷札バーコー ドによる最終照合チェックを行い出荷される.

\section{2 業務の課題}

東海物流センターのコイル業務では, コイルが在庫状態 にある間, 異材の出荷を避けるため, 何度も現品確認のた めにコイルに潜って荷札バーコードの照合チェックを 行っている.このことから挙げられる業務の課題を以下に 述べる.
(1) 倉庫内作業能率の問題

東海物流センターのコイルは倉庫内のクレーンの動作 範囲内で横に最大 50 列まで, 奥行きは約 10 番まで並べら れる. また段積みの最大段数は 4 段である。これらすべて のコイルに対して現状位置把握の調査を行う必要があり, 倉庫運営を行う作業者のほほ全員を動員して毎日約半分 の工数を使って確認作業を行っている. そのため, コイル 業務全体の能率が著しく低下し, 入出庫量の増加を妨げて いた.

(2) 不安全作業

東海物流センターで保管する対象コイルのサイズ径は $1200 \sim 1500 \mathrm{~mm}$ である. 最大 4 段に積まれると最上段で は高さが約 $5 \mathrm{~m}$ に達する。 また, 潜る距離も最大で $9.5 \mathrm{~m}$ になる列もあり，一番奥に置かれたコイルはこの距離を 潜って奥まで行く必要がある。これらのことから,コイル 潜り作業が不安全な作業であることが分かり, 実際に事故 が発生したことはないが作業者の怪我が常に危惧されて いた。

\section{3. システムの概要}

\section{1 本システムの位置付け}

東海物流センターにおけるコイルの置場を管理するた めに, 本システムでは基幹系システムと連携しコイル情報 および入荷情報・出荷情報をそれぞれ取込み, 置場内に関 しては, クレーン座標・吊り荷質量の自動検知によりコイ ル搬送を自動認識することで, コイルの位置把握を行い, 作業者に対し常に最新の置場状況を提供する.

\section{2 本システムの考え方}

(1) 情報管理

本システムで管理する情報は，コイル情報・入荷情報・ 出荷情報である.コイルの情報については, 質量・向け先 などを持ち,コイルの自動位置把握および置場状況を提供 する際に主に使用する。 入荷情報・出荷情報に関してはコ イルの入荷時・出荷時の現品照合チェック時に使用する.

(2) 置場定義 (Fig.1)

東海物流センターの置場定義としては, 東から A ヤー ド, B ヤード, Cヤード, Dヤードの順に区切られており,

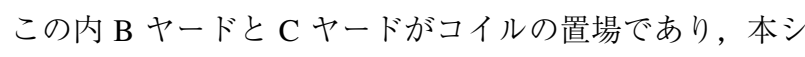
ステムの管理範囲である. また, コイルの置場範囲にも通 常ゾーンと限定ゾーンが存在し, $\mathrm{X} \cdot \mathrm{Y} \cdot \mathrm{Z}$ の座標で管理 するゾーンを通常ゾーン, X・Y のみの座標で管理する ゾーンを限定ゾーンとしている。限定ゾーンでは，コイル の手動搬送が行われる. 通常ゾーンにおける座標管理方法 は, 倉庫外の南東を座標基準点とし北方向を $\mathrm{X}$ 軸, 西方 


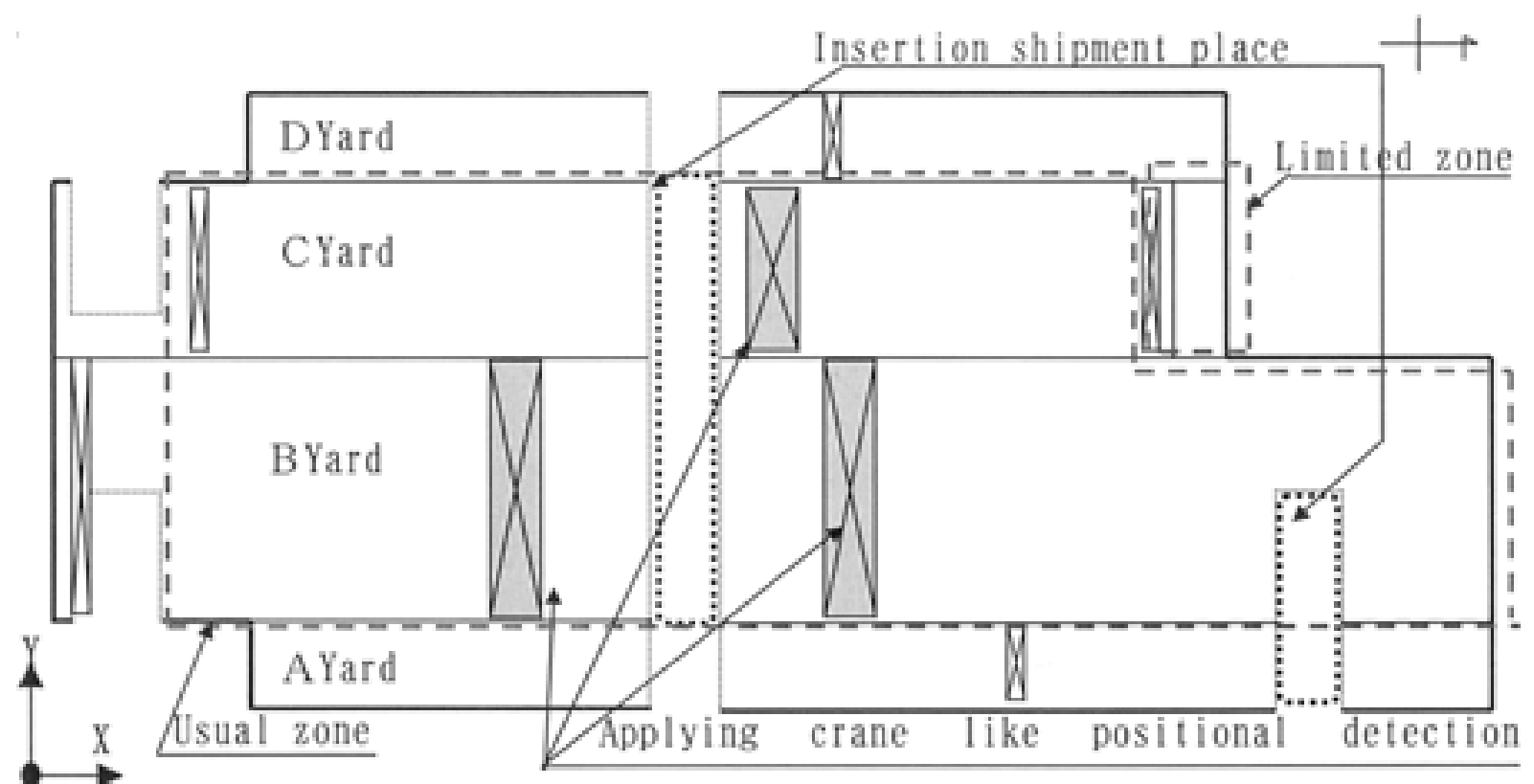

Reference point

Fig.1. Warehouse chart.

向を $\mathrm{Y}$ 軸，上方向を $\mathrm{Z}$ 軸の絶対座標として管理している. また，絶対座標の $\mathrm{X}$ 軸を各ヤードの列という単位をつけ 50 列を上限としている。 $\mathrm{Y}$ 軸は番という単位をつけ最大 30 番までを上限としている，Z 軸は単位を段とし，4 段を 上限としている.

(3) 荷定義 (Fig.2)

コイルに対して, 荷定義を以下のように行った。まずコ イル径を 1200 ～ $1500 \mathrm{~mm}$ とし，このサイズから外れるコ イルに関しては，置場を別にしてマニュアル管理とする.

(4) 入荷から出荷の流れ

ここで東海物流センターの実際のコイルの流れと本シ ステムとの関わりを述べる。

まず始めに，工場から倉庫への搬送が確定した時点で， 東海物流センターに入荷予定指示が送られる. 本システム では入荷予定指示を元にコイル情報を作成し, 実際に入荷 されてくるコイルに対する情報準備を行う。工場からト ラックが到着すると搬送されてきたコイルに随伴してい る荷札バーコードを照合チェックすることにより, 準備し ていたコイル情報とトラック上のコイルをリンクさせる.

トラック上および倉庫内におけるコイルの搬送には, ク レーンを使用する。そのクレーン座標・吊り荷質量を自動 検知することで，いくつのコイルがどの位置へ搬送された かを把握し，コイルの置場認識を行う。クレーン作業者に はクレーン運転室の視点で描写した置場イメージ画面を 提供している. 出荷予定指示がされた際の情報も置場イ

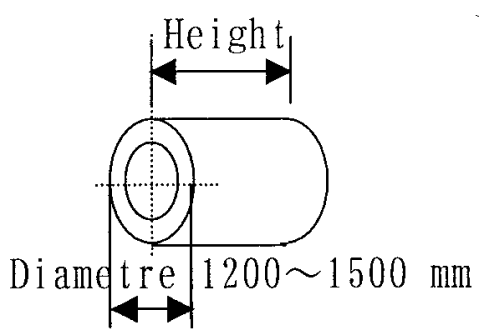

Fig.2. Definition of coil.

メージとして提供しており,クレーン作業者はその置場イ メージの表示を元に出荷準備作業を行う.

出荷トラックが到着した時点で出荷作業が行われる. 置 場イメージをもとにクレーン作業者が置場からトラック ヘコイルを搬送する.出荷トラックではコイルに随伴して いる荷札バーコードと出荷指示情報の照合チェックをし， 異材流出防止をしている.

\section{4. 置場管理とクレーンナビ}

\section{1 クレーン位置取得}

本システムの対象となるクレーン設備は B ヤードに 2 台，Cヤードに 1 台設置されており，Cフック（Fig.3）の $360{ }^{\circ} \mathrm{C}$ 旋回可能な吊り具を持ったクレーンである. 今回こ れらのクレーンから自動位置検知するにあたって対象ク レーン 1 台ごとにシーケンサ (以下, PLCという) を設置 した，位置検知方法として当初レーザ測距装置を設置し た.しかし, 走行中の振動による測距データ值の誤りや太 
陽光の干渉による測距デー夕值の誤りが発生した。また， 沜がレーザ光を遮光することによる装置異常が頻繁に発 生したことから, 測距装置を，ロータリーエンコーダ方式 に変更した.このロータリーエンコーダ方式では, クレー ンの走行・横行におけるレールのすべりによる誤差の積み 重ねが位置ずれの原因となるため, 位置補正ストライカを 追加し,クレーンがストライカを通過する時に位置補正す ることで測距誤差に対応した。

また, クレーンにはロードセルを設置し, 吊り荷の質量 を取得することでコイルの吊り・降しを自動認識させた。

コイルの吊り・降し時に PLC から位置情報 (X, Y , Z 座標）と各クレーンにロードセルを設置し C フックにて 吊り上げた質量を取得することによって，本システムの サーバで管理されている置場情報と照らし合せながらコ イルの搬送ガイダンスを提供している.

Fig.4にクレーンがコイルを吊って搬送中の写真を示す.

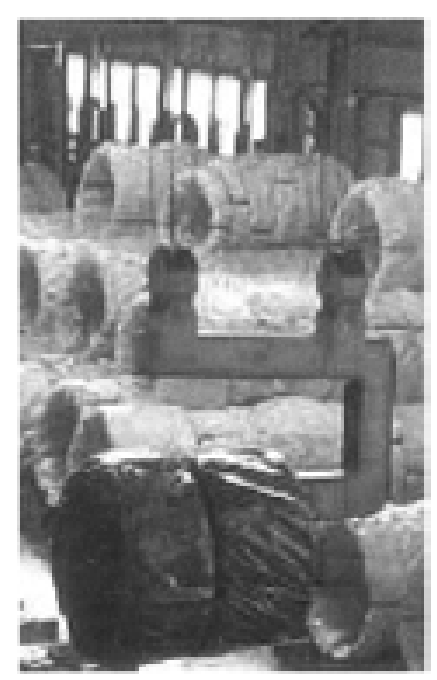

Fig.3. Photograph of the crane hook.

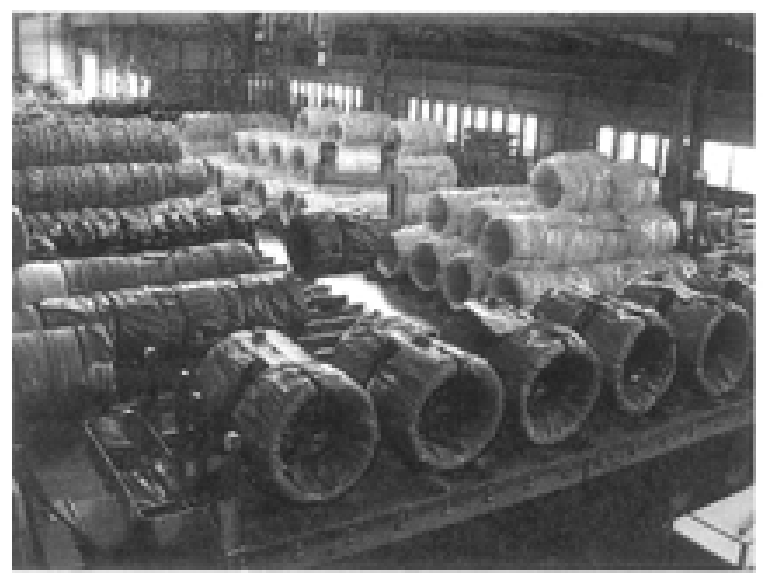

Fig.4. Hanging work in the warehouse.

\section{2 クレーンナビの役割}

クレーンナビは, クレーン運転室に設置したタッチパネ ルPCに画面表示している. そして LAN 回線で PLC と接 続し, 定周期（1 sec）にて位置情報（X, Y, Z 座標）を 取得することによって画像の視点を変化させ, クレーン作 業者がクレーン運転室の視点と近い視点で描写した置場 風景の $3 \mathrm{D}$ 動画表示を提供した. 以下にクレーンナビの機 能の概要を述べる.

(1) コイルの識別表示

コイルには, 出荷指示前・出荷指示済みなどの進渉状態 があり,クレーンナビではこれらの進渉状態をコイルの色 を分けて表示することでクレーン作業者が置場の全体状 況を把握できるようにしている (Fig.5). さらにクレーン にてコイルを吊り上げた際に, クレーン搬送中コイルの色 を変化させ, 置場にある同じ向け先のコイルの色も同タイ ミングで変化させることにより, クレーン作業者の置場配 置替え作業を支援している (Fig.6).

また, 出荷予定日が確定したコイルに対しては, その向 け先と予定日によって色分けされたマークがクレーンナ ビの表示コイルに付くことにより, クレーン作業者のその 日の作業計画立案を支援している (Fig.5).

(2) コイル情報表示

クレーン作業者が表示コイルにタッチすると, クレーン ナビはタッチされたコイルの情報をサーバ機から取得し 画面に表示している（Fig.7）。これによりクレーン作業者 はクレーンの運転室にいながらコイルの情報を知ること ができる.また，クレーンがコイルを吊り上げた際もサー バ機から吊り上げたコイルの情報を取得し, 画面に表示す るのでクレーン作業者は吊り上げたコイルが目的とする ものか否かを判別することができる（Fig.6）.

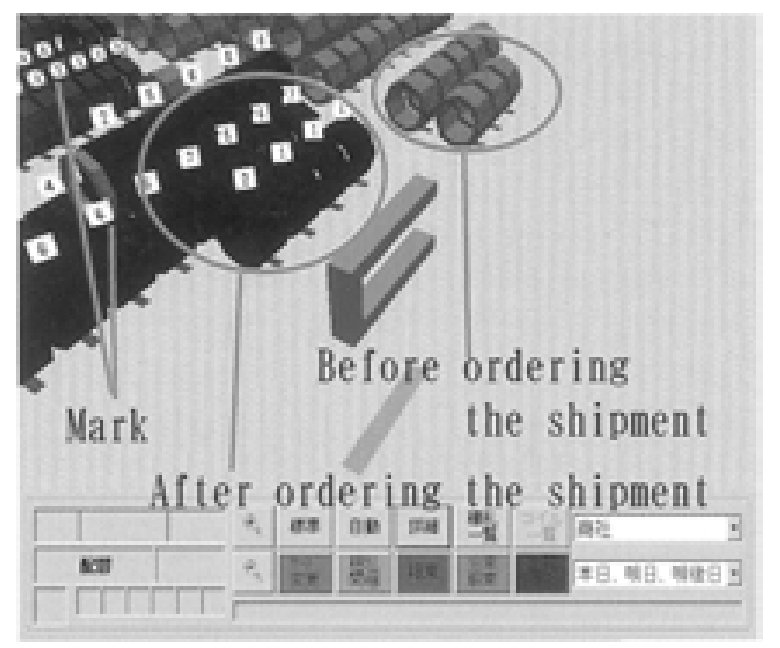

Fig.5. Coil identification display. 


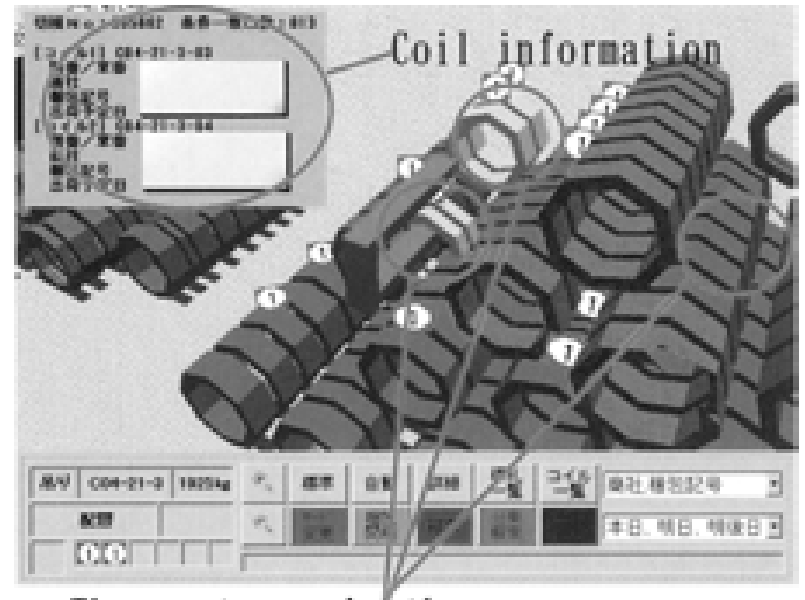

The customer is the same

Fig.6. Coil display when transported.

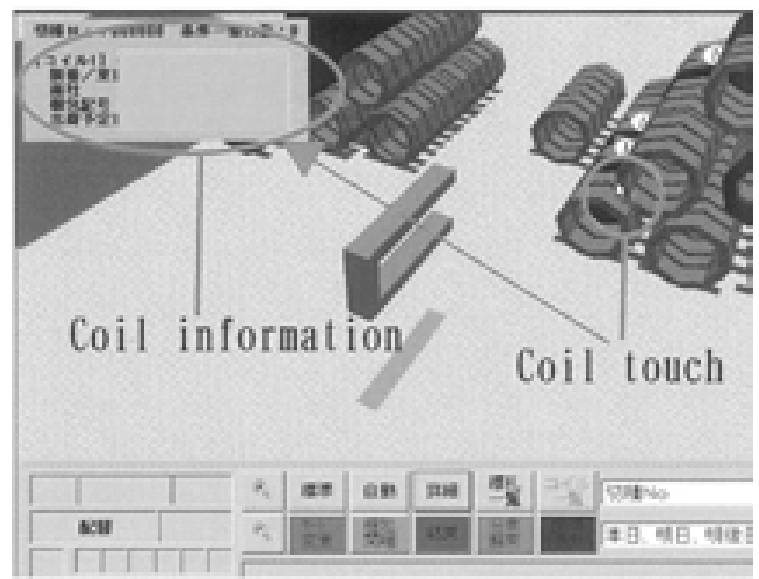

Fig.7. Touch panel display.
（3）出荷作業時の情報提供（Fig.8）

出荷作業の開始登録がされるとクレーンナビは, 出荷対 象コイルの色を変化させ，さらにコイルを点滅表示する. これによりクレーン作業者が間違いなく出荷対象コイル を搬送できるように支援している。

（4）作業中情報の提供（Fig.8）

クレーンナビは, 入荷中 - 出荷中 - 配替中 (配置替え作 業中) という現在の作業名および作業支援情報を画面左下 に表示しクレーン作業者の誤作業を防止している.

\section{3 置場座標アルゴリズム}

東海物流センターでは, Fig.9 の写真に示すように倉庫 置場にコイルを積んでいる. 各コイルの位置を正確に把握 するために, ゾーン基準值と列基準值を持つ.ゾーン基準 值は, 実測した隅点の最小 $\mathrm{X}$ 座標值, 最小 $\mathrm{Y}$ 座標值, 最 大 $\mathrm{X}$ 座標值, 最大 $\mathrm{Y}$ 座標值と, $\mathrm{Y}$ 軸の方向, 通常ゾーン か限定ゾーンかの種別, 列数および列単位の $\mathrm{X}$ 座標範囲 を持つ. 列基準值は, 各列ごとの基点 X 座標值および, 奇 数段 - 偶数段の種別と, 奇数段においては $1 \cdot 3$ 段目の境 界 Z 座標值, 偶数段においては $2 \cdot 4$ 段目の境界 Z 座標值 を持つ.これらとクレーンより取得した X, Y, Z の各座 標值により置場番地を以下のアルゴリズムにて算出し, ク レーン作業者へ置場イメージを提供している.

(1) ゾーンの算出

まず前述したゾーン基準值を線形検索し, 以下の 2 条件 を満たすゾーンがどこかを判断をする. (1) X が最小 X 座 標值以上, 最大 $\mathrm{X}$ 座標值未满, (2) $\mathrm{Y}$ が最小 $\mathrm{Y}$ 座標值以上, 最大 $\mathrm{Y}$ 座標值未満. この条件の判定によりゾーンが特定 できた場合は, 通常ゾーンか, 限定ゾーンかの判断を行

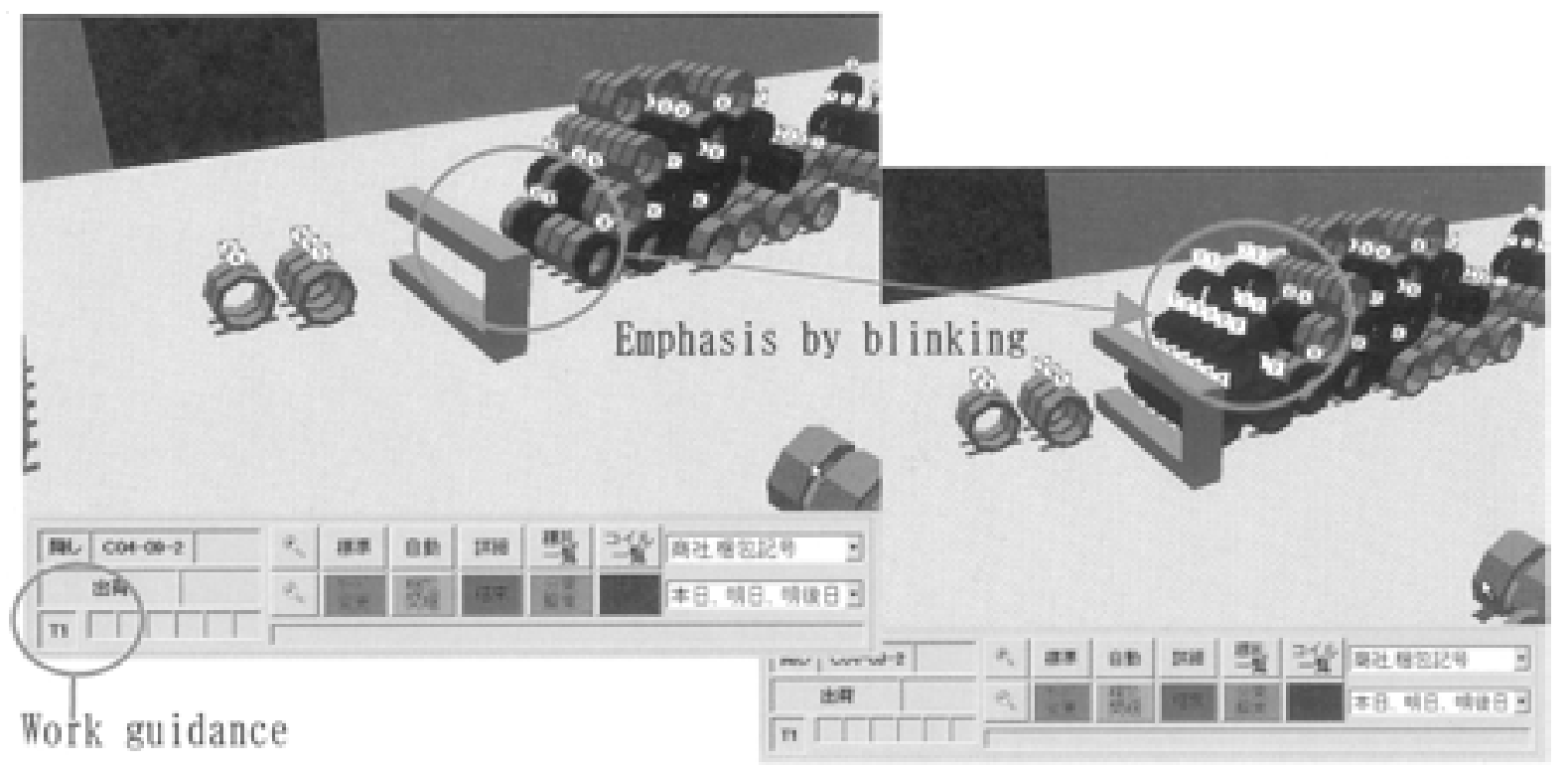

Fig.8. Shipment work display. 
う。この際，限定ゾーンであった場合はそのまま置場情報 を更新して，置場イメージの提供を行う.

(2) 列の算出

通常ゾーンであった場合は，取得した X で列基準值の 基点 $\mathrm{X}$ 座標值を検索して近似列を求め, ゾーン基準值の 列単位の X 座標範囲以内かどうかを判定して列を決定す る.

\section{(3) 段の算出}

列が決定するとその列基準值から奇数段か, 偶数段かの 種別がわかり，種別ごとの境界 $\mathrm{Z}$ 座標值と取得した $\mathrm{Z} の$ 比較により段を算出する。（Fig.9）

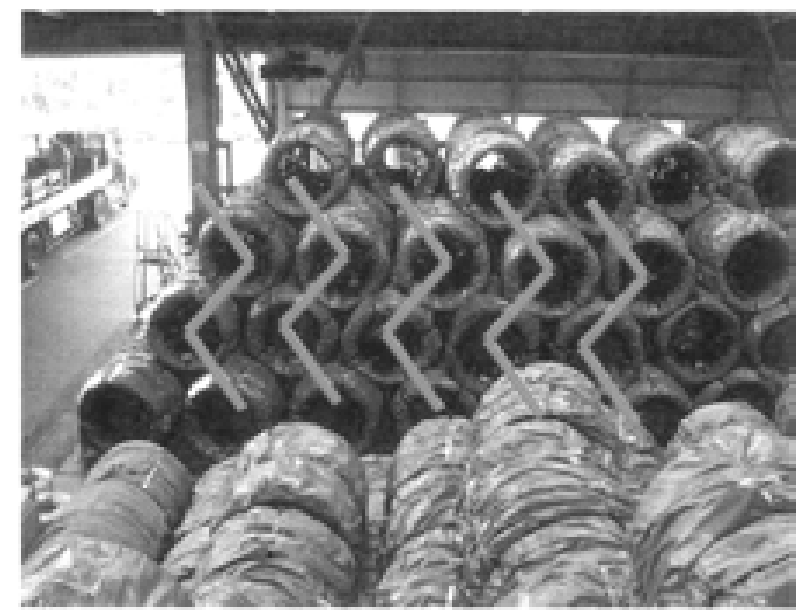

Fig.9. Place scenery photograph.

\section{4 OpenGL について}

クレーンナビにて表示する置場イメージを 3D 動画表示 する手段として OpenGL を使用した1). それによりクレー ン作業者の視点により近い視点で描写した置場風景の $3 \mathrm{D}$ 動画表示を実現した。

OpenGL とはオペレーティングシステムを特定しない, ソフトウェアインターフェイスなので極めて移植性が高 く，多くのシステムで利用することができる利点がある. OpenGL では 3D グラフィックスの表示に必要な多くのコ マンドを提供されており,これらを呼び出せば，プラット フォーム固有のサービスを使わずにプログラムできるた め, プログラム言語から OpenGL を呼び出せば，グラ フィックス処理は極めてオープンになる. Microsoft 社で は, Windows NT Ver.3.5 から，この OpenGL がカーネル の一部として組み込まれ,アプリケーションから利用する ことが可能になった。

OpenGL では, ワールド座標系の 3 次元モデルをスク リーン座標系の 2 次元映像として描画するために, (1)モデ リング変換 $\rightarrow$ (2) ビューイング変換 $\rightarrow$ (3)投影変換 $\rightarrow$ (4) ビューポート変換のプロセスによって座標変換が行われ ている. 各座標変換で行われる処理内容は, 以下に述べる (Fig.10).

(1) モデリング変換 :

3 次元 CG では，まず描画すべきモデルを計算機内に構 築する必要がある.モデリング変換では, ワールド座標系 の中で 3 次元図形の移動，回転，拡大，縮小などを行い, 描画モデルの生成を行う.
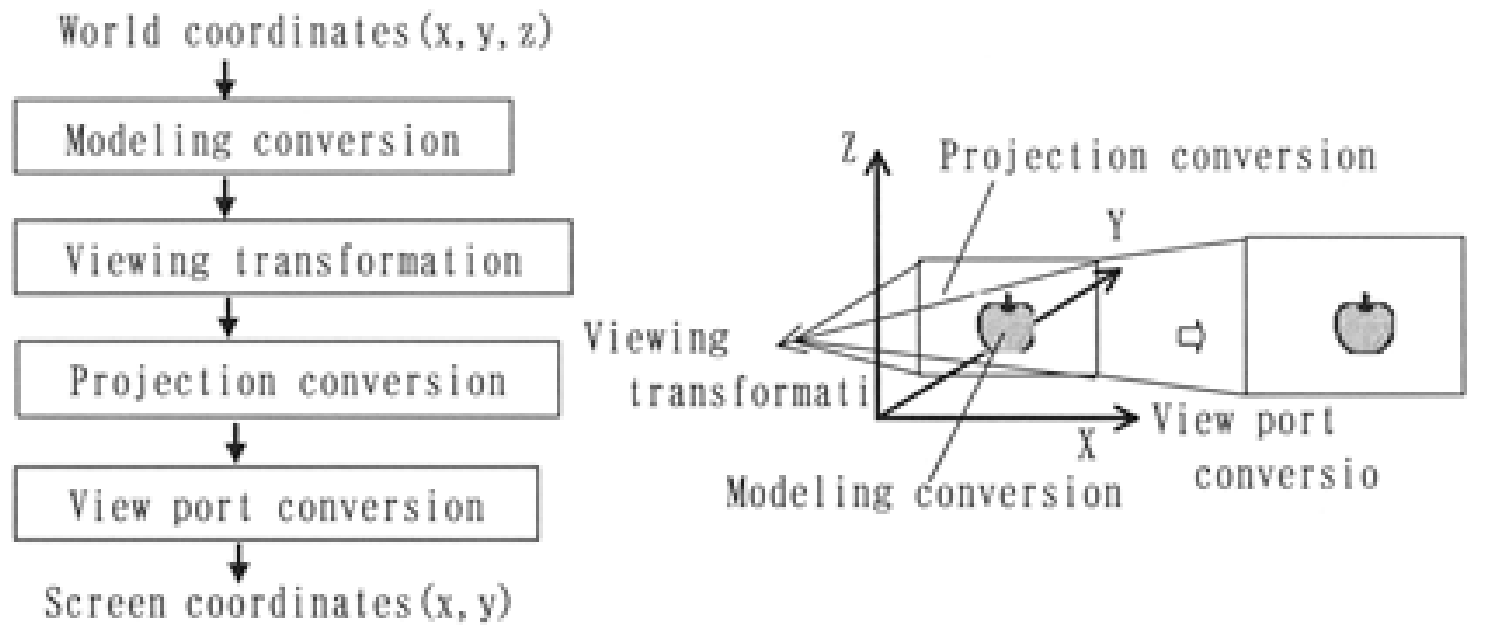

Fig.10. Mechanism of geometric transformation. 
(2) ビューイング変換：

OpenGL では，視線を原点に置き $-\mathrm{Z}$ 軸方向に向けた状 態が初期状態になっている.ビューイング変換では，ワー ルド座標系の中で設定された視点位置から見た映像を得 るための座標変換を行う.

(3) 投影変換：

ワールド座標系で表現された 3 次元モデルを 2 次元のス クリーン座標系に投影するための座標変換を行うのが投 影変換である，特に $\mathrm{VB}^{2)}$ のプログラムでは，投影線が一 点に集まる透視投影変換が行われる。

(4) ビューポート変換：

投影面に投影された 2 次元映像を, スクリーン座標系で 表されたウインドウ上の指定領域であるビューポート内 に表示するための変換を行う.

\section{5. システム導入の効果}

本システム導入により, 開発当初に目標としていた効果 は達成することができた，その内容を述べる．

定量的には, クレーンによる位置検知機能とナビゲー ション機能によって, 置場内のコイル位置が完全に把握で きたそその結果コイル内への潜り作業が大幅に削減され， 倉庫内の全体作業者人数を 8 人から 6 人へ省力を行うこと ができた。

また，コイル業務の効率を 3 割向上することができ，そ れによって入出庫量の総量が月間約 1 万 2 千 $\mathrm{t}$ から 1 万 5 千 $\mathrm{t}$ へ増加した。

定性効果としては, コイル内の潜り作業が大幅に削減さ れたことにより,倉庫内作業者がより安全に作業できる環 境を作ることに，貢献することができた。

\section{6. 結 言}

東海物流センターに掠いて,クレーンに自動位置検知機 能をつけ, 置場イメージのナビゲーション機能によって置 場状況の確認を行うことができるようになったことで, コ イル業務が大幅に改善された。今後は, 今回の開発では範 囲外として対象にしなかった，一部のコイルおよびバーな どの東海物流センター取り扱い製品を本システムの管理 対象として取り入れていけるように提案していきたい.

一方，OpenGL の技術を活用した 3D による置場イメー ジのナビゲーション機能においては, 今回開発したことで 倉庫運用を行う企業ユーザーにとっては非常に興味深い 機能であり，ニーズが高い機能であることがわかった。 今 後はこの技術のノウハウを高め, より多くのユーザーへ展 開できるように考えていきたい。
(文 献)

1) OpenGL : Silicon Graphics 社の登録商標.

2）VB：Microsoft社によって開発されたプログラミング言 語. 